\title{
A COMPOSITE MEASURE TO DETERMINE A HOST COUNTRY'S ATTRACTIVENESS FOR FOREIGN DIRECT INVESTMENT
}

\author{
Alexander Peter Groh \\ Matthias Wich
}




\title{
A COMPOSITE MEASURE TO DETERMINE A HOST COUNTRY'S ATTRACTIVENESS FOR FOREIGN DIRECT INVESTMENT
}

\author{
Alexander Peter Groh ${ }^{1}$ \\ Matthias Wich ${ }^{2}$
}

\begin{abstract}
We contribute to the question of why some countries are more attractive for foreign direct investment (FDI) than others. Therefore, we construct a composite measure that describes a host country's attractiveness for receiving FDI. This index considers all identified major, measurable and, for our scope, comparable aspects that affect FDI decisions. As a result, we can rank 127 countries with respect to their FDI attraction. The index provides the possibility of conducting detailed strength and weakness analyses for all of our sample countries and regions. These analyses provide support to policy-makers to improve their country's attraction for receiving inward FDI. They also enhance the discussion of why FDI flows still remain concentrated in advanced economies, and additionally, about the areas in which emerging and developing economies have to improve in order to narrow the existing gap. We provide correlation and sensitivity analyses to test the quality of our composite measure. Additionally, we benchmark our index with several alternative indices. Thereby, we show that no other index better tracks actual FDI activity.
\end{abstract}

JEL Codes: F15, F21, F43, 016, 057, P52, R11

Keywords: FDI, Country Comparison, Composite Measure, Index.

\footnotetext{
${ }^{1}$ Associate Professor GSCM - Montpellier Business School and Research Affiliate of the International Center of Financial Research, IESE.

${ }^{2}$ PhD Student, Darmstadt University of Technology.
} 


\section{A COMPOSITE MEASURE TO DETERMINE A HOST COUNTRY'S ATTRACTIVENESS FOR FOREIGN DIRECT INVESTMENT}

\section{Introduction}

The United Nations Conference on Trade and Development (UNCTAD, 2008a) identifies that Foreign Direct Investment (FDI) flows have risen steadily over recent decades, with various declines occurring in the early 1980s, 1990s and 2000s. This trend was partly driven by increasing corporate profits worldwide and resulting higher stock prices, which raised the value of cross-border mergers and acquisitions in all regions of the world. The OECD (Organisation for Economic Co-operation and Development) found in 2008 that FDI is a key element in the quickly evolving international economic integration. In 2007 global FDI reached a new record high with inflows of $\$ 1,833$ billion. According to UNCTAD (2008b), this surpasses the previous record by some $\$ 400$ billion. OECD (2008) emphasizes that the growth in FDI flows reflect both an increase in size and number of individual FDI transactions. Although the share of developing countries has increased, developed countries still comprised about three quarters of the world's inward FDI stocks as described by UNCTAD (2008b). UNCTAD (2006) confirms that FDI flows still remain very concentrated but demonstrates that the concentration of FDI flows between certain countries is considerably lower than in the 1980s, when only a small number of countries received FDI, and the 1990s, when large-scale mergers and acquisitions distorted the FDI distribution. Taking all these factors into account, FDI plays a significant role in the development of international trade, and it tends to establish direct, stable and long-lasting links between economies. OECD (2008) discusses that FDI can serve as an important vehicle for local enterprise development and, in addition, it can strengthen the competitiveness of both the recipient ("host") and the investing ("home") economy.

The decision-making process of a foreign investor is very complex and has been broadly discussed in literature. Many factors have been identified by researchers that, depending on the industrial sector and regional differences, are meant to influence FDI flows around the globe. In addition, a number of indices exist that measure a country's potential in attracting inward FDI by taking different combinations of determining factors into account. Some of these indices target policy-makers to enable comparisons of the investment environment of countries and to support policy analyses. The question behind these analyses is how policy-makers can induce changes in order to increase the country's attraction for inward FDI. Unfortunately, the quality of these indices remains unclear. 
The aim of this paper is to identify the determinants for FDI decisions in literature, and to provide an explanation of why some countries are more attractive for foreign investors than others. Therefore, a composite index that adequately describes a host country's attraction for FDI is constructed. This index, henceforth referred to as FDI Country Attractiveness Index or just FDI Index, considers all identified major, measurable and, for our scope, comparable aspects that affect FDI decisions. As a result, it ranks a set of countries according to their attractiveness for receiving inward FDI. Additionally, due to its structure, the index provides the possibility of conducting detailed strength and weakness analyses for both countries and regions. These analyses can be used by policy-makers to draw conclusions on how to improve the country's attraction for receiving inward FDI. To give an example on how policy-makers can identify existing obstacles that prevent foreign investors from investing in a particular country or region, a comparison of the strengths and weaknesses of advanced economies and emerging/developing economies is conducted. This analysis gives an explanation for the question of why FDI flows still remain concentrated on advanced economies, and additionally, the areas in which emerging and developing economies have to improve the most in order to close the existing gap are identified. To determine the quality of "Our FDI Index", correlation and sensitivity analyses are conducted. Additionally, the index results are benchmarked against different kinds of alternative indices. Thereby, we show that the effort to calculate our index is justified because no other index better tracks actual FDI activity.

The paper starts with a literature overview of significant determinants of FDI decisions. In a subsequent section, we introduce the data and our sample countries. This is followed by a description of the construction technique of our index. We present the results and discuss the detected general differences between emerging and developed economies. Then, we confirm the quality of Our FDI Index by correlating the index scores with the actual FDI activity in the particular countries and by benchmarking it with other indices. Finally, we summarize and conclude.

\section{Related Literature}

It is probably related to the poor availability of cross sectional country data in the past that there are not many contributions focusing on the constructions of a composite measure similar to ours. Two notable exceptions are UNCTAD's Investment Compass ${ }^{1}$ and UNCTAD's Inward FDI Potential Index. ${ }^{2}$ The investment compass comprises 60 different indicators based on international statistics, and surveys conducted by UNCTAD. The Inward FDI Potential Index captures 12 variables. We will return later to these two indices and benchmark Our FDI Index against them. The only paper that deals with a similar topic is Pantelidis and Nikolopoulos (2008). They calculate a FDI attractiveness index for the European countries, and use 31 different indicators grouped into seven major categories. However, they focus on Greece, and draw their conclusions for improving the investment conditions there.

While there is not much literature on similar composite measures, the contributions on FDI determinants themselves are exhaustive, and largely beyond the scope of this paper. Comprehensive literature overviews can be found, e.g., in Blonigen (2005), Chakrabarti (2001), Lim (2001), Markusen (2000), Moosa and Cardak (2006), Franco et al. (2008), Clausing and

\footnotetext{
${ }^{1}$ See http://compass.unctad.org.

${ }^{2}$ See http://www.unctad.org/Templates/WebFlyer.asp?intItemID=2472\&lang=1.

2 - IESE Business School-University of Navarra
} 
Dorobantu (2005), and Singh and Jun (1995). A large body of papers examines how external factors affect firm-level decisions. Another body of literature focuses on fundamental countrylevel factors and how they affect aggregate country-level FDI activity. The latter strand represents our perspective. For our composite measure, we need to determine the included factors for assessing FDI country attractiveness. Therefore, we discuss the contributions that detect determinants of a host country for inward FDI. In the following section, we provide an overview of the most important parameters that affect aggregated country-level FDI activity. We group the determinants into four categories: Economic Activity, Legal and Political Environment, Business Environment, and Infrastructure. These categories likewise build the framework of our index. We try to assess the key driving forces with data series available for all of our sample countries.

\subsection{Literature on the Importance of Economic Activity}

Intuitively, the state of a particular country's economy affects FDI activity. Shatz and Venables (2000) find that the market size is very important to determine the foreign markets in which firms invest. They argue that the majority of FDI is horizontal, ${ }^{3}$ with the focus on serving customers in the host-country market rather than in the worldwide market. Fung et al. (2002) examine the determinants of FDI from the United States and Japan in China using a regional data set. They find that the absolute level of Gross Domestic Product (GDP) has a significant positive impact on inflows of FDI from all sources. Billington (1999) stresses that, besides a high GDP, the growth of an economy has a positive effect on the inflow of FDI. Wheeler and Mody (1992) argue that rapid industrial growth and an expanding domestic market are especially important for developing countries. Kobrin (1976) tests the hypothesis that a substantial proportion of the variance of flows of manufacturing FDI among host countries can be explained by indicators of market size and potential. He finds that market size is one of the primary determinants of FDI. Nigh (1986) investigates the determinants on United States manufacturing direct investments in Latin America and emphasizes that the host country's market size and market growth affect the direct investment decisions concerning countries in Latin America. Torrisi et al. (2008) find that market size is a critical factor for the Central European transition economies like Hungary, Poland, the Czech Republic and Slovakia. They add that a dynamic economy and appropriate economic growth policies are essential for attracting FDI inflows. A positive effect from market size and/or market growth on FDI inflows is likewise found by Root and Ahmed (1979), Scaperlanda and Mauer (1969), Kravis and Lipsey (1982), Barrell and Pain (1996), Milner and Pentecost (1996), Janicki and Wunnava (2004), Vogiatzoglou (2007), and Bénassy-Quéré et al. (2007).

The state of a particular country's economy is not only determined by market size and growth. Addison and Heshmati (2003) find that the openness to trade is a significant determinant, especially for Latin America, and conclude that economies in which trade is important also have relatively higher FDI. They argue that these countries may pursue policies that are more attractive for foreign investors. Asiedu (2002) analyzes the determinants of inward FDI flows for developing countries and concludes that the impact of an economy's openness to FDI depends on the type of investment. She furthermore finds that openness to trade has a positive impact on FDI flows. Janicki and Wunnava (2004) argue that openness to trade is an important

\footnotetext{
${ }^{3}$ Essentially, horizontal FDI is where multi-plant companies approximately duplicate the same activities in multiple countries; vertical FDI is where firms locate different production stages in different countries. For a detailed discussion of the differences between horizontal and vertical FDI see Caves (1971).
} 
determinant and explain that trade and investments complement each other. Likewise, Bevan and Estrin (2004), who study the determinants of FDI from Western countries to Central and Eastern European countries, conclude that FDI and trade are complementary because countries that have higher trading shares with Western countries also receive significantly more FDI. Nonnenberg and Cardoso de Mendonça (2004) stress that the openness of an economy is a proxy for the willingness of a country to accept FDI and find that it is an important factor in attracting capital. Al Nasser (2007), Akhter (1993), and Torrisi et al. (2008) receive similar results and conclude that the openness of an economy enhances FDI.

Baniak et al. (2005) explore important factors that determine the flow of FDI into transition countries and show that macroeconomic instability reduces inward FDI. Al Nasser (2007) focuses on 19 Latin American and Asian countries and stresses that, besides the fundamental economic factors such as market size and GDP growth, macroeconomic stability likewise affects the FDI inflow. Schneider and Frey (1985) find that, in addition to the country's level of development measured by real per capita Gross National Product (GNP), the balance of payment is one of the most important economic parameters. They conclude that the higher the per capita income and the lower the balance of payments deficit, the more FDI is attracted.

\subsection{Literature on the Importance of the Legal and Political System}

The legal and political system also affects a country's appeal for FDI investors. Ramcharran (2000) finds that regulatory and country risk factors have an impact on FDI inflows in Central and Eastern Europe. Therefore, he analyzes the implications of reform packages implemented in the 1990s by the CEE countries aiming to develop market oriented economies. He shows that regulatory and risk reduction factors contributed positively to FDI and that an unaccommodating legal environment and country risks are main deterrents of FDI. Baniak et al. (2005) find that legal stability is crucial for stimulating FDI inflows, and increasing transparency regarding the legal framework of a country affects FDI decisions. Naudé and Krugell (2007) confirm this and emphasize that the regulatory burden and the rule of law are robust determinants of FDI. Finally, UNCTAD (2008b) confirms that the creations of participatory, transparent, and accountable governance systems that promote and enforce the rule of law are critical. Naudé and Krugell (2007) argue that, in addition to the quality of the legal system, political stability plays a significant role in attracting FDI. According to Ramcharran (1999), political instability in terms of civil wars, illegal capital flight, financial market instability and political corruption have significant effects on FDI. Akhter (1993) mentions that political instability can negatively impact business activities and is, therefore, an important factor for FDI. Nigh (1985) analyzes the effect of political events on FDI decisions in the United States manufacturing industry, and indicates that political events influence the decision process of investors. The extent to which the political environment affects FDI depends on the country's development. Nigh (1986) concludes that both intra- and inter-nation conflicts have an impact on FDI inflows concerning Latin American countries. Schneider and Frey (1985) show that political instability significantly reduces the inflow of FDI. Root and Ahmed (1979) identify political instability as one of the main obstacles for developing countries to realize any substantial increases in FDI.

\subsection{Literature on the Importance of the Business Environment}

The business environment in a particular country is another key driving force for FDI inflows. Janicki and Wunnava (2004) argue that labor costs are a key determinant for FDI inflows in 
Central and Eastern European countries. Barrell and Pain (1996) also find that labor costs are an important factor for investment decisions. Rodriguez and Pallas (2008) stress that the difference between the productivity of labor and its cost play a key role in explaining FDI. They find that investors are not solely motivated by the evolution of labor costs. Furthermore, they argue that human capital, a fundamental element of increased per-worker labor productivity, is likewise a significant determinant of FDI inflows. The importance of human capital is also cited by Miyamoto (2003), Noorbakhsh et al. (2001), and Saggi (2002).

Hartman (1984) discusses that the possible impacts of host country tax policy on FDI are complex, but he comes to the conclusion that FDI decisions are strongly affected by changes in the tax policy. Cassou (1997) confirms that tax policies have an impact on FDI flows between the United States and other countries. Wei (2000a) likewise concludes that a rise in tax rate on multinational firms reduces inward FDI.

Baniak et al. (2005) find that the time requirements and the complexity of bureaucratic procedures influence the expected utility from profit, thereby affecting the results of FDI decisions. Bénassy-Quéré et al. (2007) confirm that bureaucracy is an important determinant for FDI inflow. In addition, Bénassy-Quéré et al. (2007) find that corruption tends to reduce FDI inflows. Wei (2000a and 2000b) confirms this. He stresses that corruption affects both the volume and the composition of capital inflows and thus significantly reduces inward FDI flows.

\subsection{Literature on the Importance of Infrastructure}

The infrastructure of a particular country is also an important factor for FDI investors. Loree and Guisinger (1995) find that a developed communication and transportation infrastructure has a positive influence on inward FDI flows. Wheeler and Mody (1992) conclude that, for developing countries, infrastructure is one of the dominating determinants for FDI decisions. Root and Ahmed (1979) confirm this and add that investors are attracted to developing countries whose governments are directly participating in infrastructure programs. Al Nasser (2007) supports these findings for FDI decisions in Latin America. Addison and Heshmati (2003) stress that the infrastructure of information and communication technology (ICT) has a strong impact on inward FDI. They suggest that there should be more assistance for poorer countries to help them adopt ICT.

\subsection{Summary of the Literature Review}

Research as outlined above emphasizes the difficulty of identifying the appropriate parameters for our composite measure. There is neither consensus about the most important parameters for FDI activity nor any ranking. While some parameters are more comprehensively discussed, and certainly of very high relevance, it remains unclear how these interact. For example, it is debatable whether the FDI activity in a country with a high-quality legal system is more affected by the cost of labor or by its infrastructure. For the index calculation, it would be ideal to include all the presented parameters. However, some of the cited papers focus on particular economies or regions, depending on the data available, and their datasets are neither available nor comparable to the datasets that exist for the large number of countries we aim to cover. Hence, we try to find the best possible proxies for the aforementioned drivers of FDI. From the foregoing review of prior research, we identified four main criteria that ultimately determine inward FDI activity: Economic Activity, Legal and Political Environment, Business Environment, and Infrastructure. We regard these criteria as "key drivers" or "level one indices," and base the index structure upon 
them. Since none of the key drivers is directly measurable, we search for data series that adequately express their character. For example, we seek appropriate data to proxy Infrastructure. Altogether, we find 20 individual data series to describe the four key drivers. We define subconstructs and group data series when they share a common character (e.g., "4.1 Transportation" in Table 1). We refer to these sub-constructs as second level indices and, in a first step, aggregate the data on the third level to concentrate information. The next step is to aggregate the second level indices to the four key drivers and then to the overall index. An important issue is the determination of the weights of the individual data series and constructs for their aggregation. We describe the structure of our constructs, and methodologies for determining the aggregation and weighting of the index in the following section.

\section{Data and Methodology to Construct Our FDI Index}

Composite indicators are used to summarize a number of underlying individual indicators or variables. They are quantitative or qualitative measures derived from a series of observed facts that can reveal or proxy characteristics. A good description is given by Nardo et al. (2005a). Our goal is to gather data for a large number of countries from all regions of the world to assess the above defined key driving forces for FDI.

\subsection{Data Series}

The selection of our data series does not finally depend on the question of what is necessary and most adequate to assess FDI attractiveness; the constraint is data availability to maximize our country sample. We finally detect 20 different data series that we regard as adequate proxies for the discussed key drivers. These data series, additional denominators, the units and sources, and the index structure are presented in Table 1.

Table 1 reveals that we use several databases with annual data ranging from 2000 to 2008 and usually refer to the last data record. To smooth fluctuation, some of the data points are averaged over a period of three years. To ensure comparability we deflate some data series either by GDP or by population. Not all data series are raw data, but represent ready-made indices, such as the "Worldwide Governance Indicators" ${ }^{4}$ from World Bank. The index structure is based on three levels. The first is the level of the four key driving forces. The second level consists of data series, or sub-indices, which are themselves aggregated from the level three data series. The main advantage of the index structure is that it allows tracing back key driver values to increasing levels of detail. This is important for the subsequent analyses of strengths and weaknesses of particular countries or regions. Additionally, due to this kind of pyramidal structure, data series on a lower index level do not gain too much weight in the aggregation process.

\footnotetext{
${ }^{4}$ See http://info.worldbank.org/governance/wgi/index.asp.

6 - IESE Business School-University of Navarra
} 


\section{Table 1}

Index structure, data series, their units and sources

\begin{tabular}{|c|c|c|c|}
\hline Identifier & $\begin{array}{l}\text { Key Drivers, } \\
\text { Construct, Data Series }\end{array}$ & Unit & Source \\
\hline Denom. 1 & Population & [millions] & $\begin{array}{l}\text { IMF, UNFPA State of World Population } 2008 \text { for values in 2008, } \\
\text { UNFPA State of World Population } 2007 \text { for values in } 2007\end{array}$ \\
\hline Denom. 2 & Total GDP & [US\$ millions] & $\begin{array}{l}\text { Euromonitor International from International Monetary Fund (IMF), } \\
\text { International Financial Statistics }\end{array}$ \\
\hline \multicolumn{4}{|c|}{ 1. Economic Activity } \\
\hline 1.1 & Market Size and Potential & & \\
\hline 1.1 .1 & $\begin{array}{l}\text { Economic Size per Capita (GDP } \\
\text { PPP per capita) }\end{array}$ & [per capita] & IMF, World Economic Outlook Database (October 2008) \\
\hline 1.1 .2 & Real GDP y-o-y Growth & {$[\%$ rate $]$} & $\begin{array}{l}\text { Euromonitor International from International Monetary Fund (IMF), } \\
\text { International Financial Statistics and World Economic } \\
\text { Outlook/UN/national statistics }\end{array}$ \\
\hline 1.2 & $\begin{array}{l}\text { Economic Openness (Prevalence of } \\
\text { Trade Barriers) }\end{array}$ & [\#] & $\begin{array}{l}\text { World Economic Forum, The Global Competitiveness Report 2008- } \\
2009 \text { from Executive Opinion Survey 2007, } 2008\end{array}$ \\
\hline 1.3 & $\begin{array}{l}\text { Economic Stability (Central } \\
\text { Government Gross Surplus/Deficit) }\end{array}$ & {$[\%$ of GDP] } & $\begin{array}{l}\text { World Economic Forum, The Global Competitiveness Report 2008- } \\
2009 \text { from IMF, World Economic Outlook Database (April 2008); IMF } \\
\text { country reports; European Central Bank; European Bank for } \\
\text { Reconstruction and Development; African Development Bank; } \\
\text { Economist Intelligence Unit, Country Data Database (June 2008); } \\
\text { national sources }\end{array}$ \\
\hline \multicolumn{4}{|c|}{ 2. Legal and Political System } \\
\hline 2.1 & Legal System & & \\
\hline 2.1.1 & Rule of Law & {$[\#]$} & World Bank, WGI (Worldwide Governance Indicator) \\
\hline 2.1.2 & Regulatory Quality & {$[\#]$} & World Bank, WGI (Worldwide Governance Indicator) \\
\hline 2.1 .3 & Legal Enforcement of Contracts & {$[\#]$} & Fraser Institute \\
\hline 2.1 .4 & Business Impact on FDI & {$[\#]$} & $\begin{array}{l}\text { World Economic Forum, The Global Competitiveness Report 2008- } \\
2009 \text { from Executive Opinion Survey 2007, } 2008\end{array}$ \\
\hline 2.2 & Political System & & \\
\hline 2.2 .1 & $\begin{array}{l}\text { Political Stability and Absence of } \\
\text { Violence/Terrorism }\end{array}$ & {$[\#]$} & World Bank, WGI (Worldwide Governance Indicator) \\
\hline 2.2 .2 & Government Effectiveness & [\#] & World Bank, WGI (Worldwide Governance Indicator) \\
\hline \multicolumn{4}{|c|}{ 3. Business Environment } \\
\hline 3.1 & Labor Costs (Pay and Productivity) & {$[\#]$} & $\begin{array}{l}\text { World Economic Forum, The Global Competitiveness Report 2008- } \\
2009 \text { from Executive Opinion Survey 2007, } 2008\end{array}$ \\
\hline 3.2 & Taxation (Profit and Capital Gains Tax) & {$[\%$ rate $]$} & Doing Business \\
\hline 3.3 & $\begin{array}{l}\text { Bureaucracy (Administrative } \\
\text { Requirements) }\end{array}$ & {$[\#]$} & Fraser Institute \\
\hline 3.4 & Corruption (Control of Corruption) & {$[\#]$} & World Bank, WGI (Worldwide Governance Indicator) \\
\hline \multicolumn{4}{|c|}{ 4. Infrastructure } \\
\hline 4.1 & Transportation & & \\
\hline 4.1.1 & Quality of Roads & {$[\#]$} & $\begin{array}{l}\text { World Economic Forum, The Global Competitiveness Report 2008- } \\
2009 \text { from Executive Opinion Survey 2007, } 2008\end{array}$ \\
\hline 4.1.2 & Quality of Railroad Infrastructure & {$[\#]$} & $\begin{array}{l}\text { World Economic Forum, The Global Competitiveness Report 2008- } \\
2009 \text { from Executive Opinion Survey 2007, } 2008\end{array}$ \\
\hline 4.1.3 & Quality of Port Infrastructure & {$[\#]$} & $\begin{array}{l}\text { World Economic Forum, The Global Competitiveness Report 2008- } \\
2009 \text { from Executive Opinion Survey 2007, } 2008\end{array}$ \\
\hline 4.1.4 & Quality of Air Transport Infrastructure & {$[\#]$} & $\begin{array}{l}\text { World Economic Forum, The Global Competitiveness Report 2008- } \\
2009 \text { from Executive Opinion Survey 2007, } 2008\end{array}$ \\
\hline 4.2 & Energy (Quality of Electricity Supply) & {$[\#]$} & $\begin{array}{l}\text { World Economic Forum, The Global Competitiveness Report 2008- } \\
2009 \text { from Executive Opinion Survey 2007, } 2008\end{array}$ \\
\hline 4.3 & $\begin{array}{l}\text { ICT Infrastructure (Fixed Line and } \\
\text { Mobile Phone Subscribers) }\end{array}$ & [per capita] & World Bank, World Development Indicator \\
\hline
\end{tabular}




\subsection{Country Sample}

The choice of whether a country is included in our index is driven by the availability of the data series. The objective was to find an adequate data set and a large number of countries in all regions of the world as well as in different development stages. Table 2 presents the countries covered, grouped into geographic regions. The country list consists of 127 countries grouped into 8 regions.

\section{Table 2}

Countries covered, assigned to different regions

\begin{tabular}{|ll|}
\hline Region & Countries covered \\
Africa: & Algeria, Benin, Botswana, Burkina Faso, Burundi, Cameroon, Chad, Côte \\
& d'Ivoire, Egypt, Ethiopia, Ghana, Kenya, Lesotho, Libya, Madagascar, Malawi, \\
& Mali, Mauritania, Mauritius, Morocco, Mozambique, Namibia, Nigeria, Senegal, \\
& South Africa, Suriname, Tanzania, Trinidad and Tobago, Tunisia, Uganda, \\
& Zambia, Zimbabwe \\
Asia: & Azerbaijan, Bangladesh, China, Hong Kong, India, Japan, Kyrgyz Republic, \\
& Nepal, Pakistan, Republic of Korea, Russian Federation, Tajikistan \\
Asia Pacific and Oceania: & $\begin{array}{l}\text { Australia, Brunei, Cambodia, Indonesia, Malaysia, New Zealand, Philippines, } \\
\text { Singapore, Taiwan, Thailand, Timor-Leste, Vietnam }\end{array}$ \\
Eastern Europe: & $\begin{array}{l}\text { Albania, Armenia, Bosnia and Herzegovina, Bulgaria, Croatia, Cyprus, Czech } \\
\text { Republic, Estonia, Georgia, Hungary, Latvia, Lithuania, Macedonia, Malta, } \\
\text { Moldova, Montenegro, Poland, Romania, Serbia, Slovakia, Slovenia, Ukraine }\end{array}$ \\
Latin America: & $\begin{array}{l}\text { Argentina, Barbados, Bolivia, Brazil, Chile, Colombia, Costa Rica, Dominican } \\
\text { Republic, Ecuador, El Salvador, Guatemala, Guyana, Honduras, Jamaica, } \\
\text { Mexico, Paraguay, Peru, Puerto Rico, Uruguay, Venezuela }\end{array}$ \\
Middle East: & $\begin{array}{l}\text { Bahrain, Israel, Kuwait, Oman, Qatar, Saudi Arabia, Syria, Turkey, United } \\
\text { Arab Emirates }\end{array}$ \\
North America: & Canada, United States \\
Western Europe: & $\begin{array}{l}\text { Austria, Belgium, Denmark, Finland, France, Germany, Greece, Iceland, } \\
\text { Ireland, Italy, Luxembourg, Netherlands, Norway, Portugal, Spain, Sweden, } \\
\text { Switzerland, United Kingdom }\end{array}$ \\
& \\
&
\end{tabular}

Table 2 presents the countries we include in our analyses and the region they are assigned to. Thereby, we follow the regional clustering of the IMF. The selection of the countries depends purely on the availability of the dataset.

\subsection{Index Calculation}

On the basis of the data and country sample introduced in the previous sections, the index calculation can now be conducted. Nardo et al. (2005a) give a good overview about how to construct a composite indicator. The index calculation methodology used in this paper follows the approach of Nardo et al. (2005a) and can be divided into the four steps illustrated in Figure 1. This paper, therefore, focuses on the most common methods to calculate a composite index; for a more detailed discussion of the index construction process and detailed descriptions of the possible methods that can be used to calculate a composite index, see Nardo et al. (2005a). 


\section{Figure 1}

Index calculation methodology

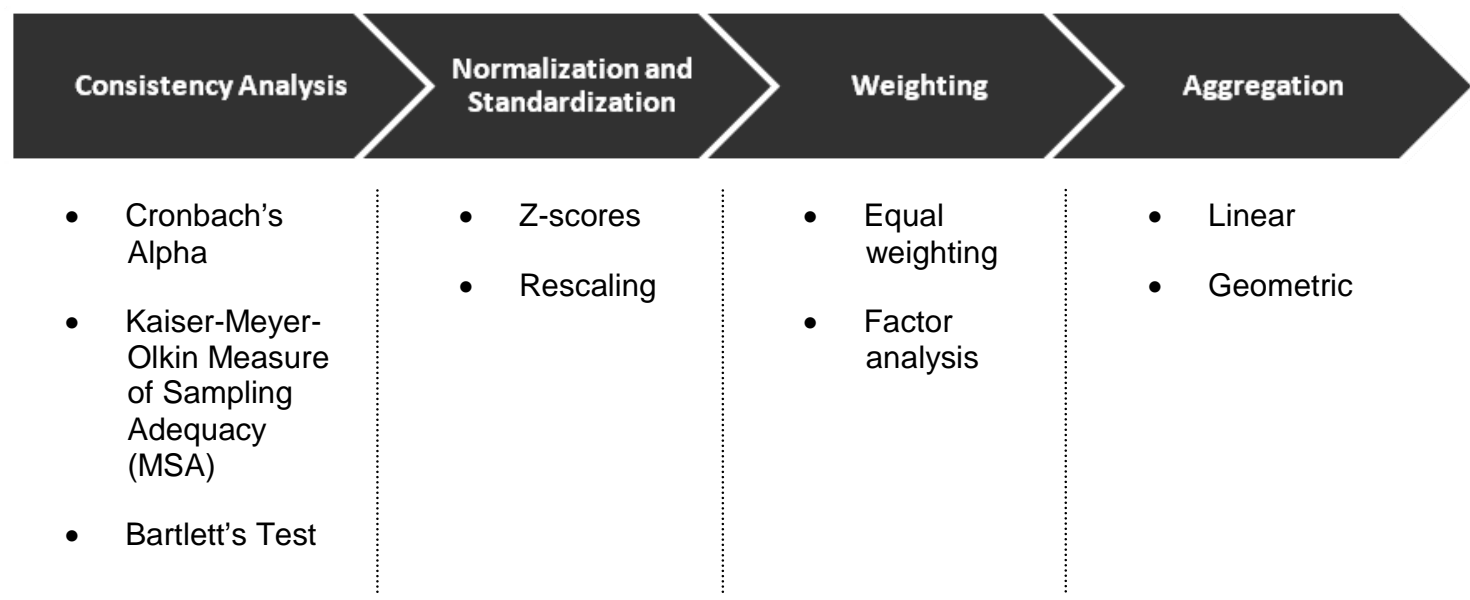

The following sections briefly describe the techniques used to analyze the index consistency, to normalize and standardize the data, to determine the weightings of the indicators, and finally to aggregate them to obtain the index results. The results are sensitive to the techniques used for the calculation. Therefore, we use different combinations of the proposed methods to calculate four different index versions. The explanatory power of the results of these index versions will be compared in a subsequent section to detect which combination yields the best result and therefore the most adequate measure to determine a host country's attraction for FDI.

\section{Table 3}

Different methods to calculate the index

\begin{tabular}{|cccc|}
\hline Method & $\begin{array}{c}\text { Normalization and } \\
\text { Standardization }\end{array}$ & Weighting Scheme & Aggregation \\
\hline $\mathbf{1}$ & Z-Score & Equal & Linear \\
$\mathbf{2}$ & Rescaling & Equal & Geometric \\
$\mathbf{3}$ & Rescaling & Equal & Geometric \\
\hline
\end{tabular}

\subsubsection{Analysis of Index Consistency}

With the consistency analyses we demonstrate that the raw data and the ready-made indices are consistent for their aggregation. However, they are recommended prior to factor analyses to determine whether the results of the factor analyses are plausible. Literature, such as Raykov (1998), Cortina (1993), Feldt et al. (1987), Green et al. (1977), Hattie (1985), and Miller (1995), amply covers the use of Cronbach's Alpha and other measures such as the Kaiser-Meyer-Olkin Measure of Sampling Adequacy (MSA), and Bartlett's Test of Sphericity. 
Cronbach's Alpha ${ }^{5}$ is applicable for an estimate of the internal consistency of items in a model or survey. It assesses the degree of the correlations among a set of variables and is used within this paper to evaluate how well a set of sub-indices measures a single unidimensional object.

Cronbach's Alpha is defined as:

$$
\alpha=\frac{n \bar{R}}{1+(n-1) \bar{R}}
$$

where

$\mathrm{n}$ = number of the components of a (sub-) index

$\bar{R}=$ mean correlation of the items

Cronbach's Alpha is zero if no correlation exists and the sub-indices are independent. If the underlying items are perfectly correlated, it is equal to one. Therefore, a high Cronbach's Alpha is an indication that the underlying items proxy the desired variable well. According to Nunnally (1978), a value of 0.7 is an acceptable threshold.

The other two measures are related to factor analyses. The Kaiser-Meyer-0lkin measure of sampling adequacy (MSA) is based on the partial correlations among the input variables, and should be $>=0.5$ to proceed with factor analysis as described by Kaiser and Rice (1974). ${ }^{6}$ Bartlett's Test of Sphericity reveals whether the correlation matrix is not an identity matrix and, therefore, can be factorized. Its test value should be below the 0.05 significance level.

\section{Table 4}

Consistency analyses for our data

\begin{tabular}{|l|c|c|c|}
\hline Key Drivers & Cronbach's Alpha & MSA Value & Bartlett's Test \\
\hline 1. Economic Activity & 0.617 & 0.610 & 0.000 \\
\hline 2. Legal and Political System & 0.908 & 0.862 & 0.000 \\
\hline 3. Business Environment & 0.522 & 0.546 & 0.000 \\
\hline 4. Infrastructure & 0.894 & 0.705 & 0.000 \\
\hline
\end{tabular}

The Cronbach's Alphas for the data used to assemble the key drivers Economic Activity and Business Environment are below Nunally's cut-off value of 0.7. More detailed analyses reveal that, for Economic Activity, we should discard the GDP growth rate from the selection to increase the Cronbach Alpha. This is caused by the lack of correlation of GDP growth with the other criteria. For the Business Environment, our indicator for taxation correlates poorly with the others, and thus should be discarded to improve the results in a statistical sense. However, we follow the economic rationale based on previous literature on this topic, which regards these two criteria as important for a country's attraction of FDI, and therefore we keep them.

\footnotetext{
${ }^{5}$ Cf. Cronbach (1951).

${ }^{6}$ Cf. Cureton and D'Agostino (1993). 


\subsubsection{Normalization and Standardization}

In order to realize index aggregation, all data points need to be normalized. An overview of various methods and a discussion about the particular advantages and disadvantages can be found in Freudenberg (2003), Jacobs et al. (2004), and Nardo et al. (2005a). Ebert and Welsch (2004) argue that z-scores and the rescaling approach are the most commonly used methods because of their desirable characteristics regarding to aggregation. Therefore, this paper uses these methods for normalization and standardization.

Z-scores convert the underlying data to a common normally distributed scale, with a mean of zero and a standard derivation of one. This leads to the result that variables with extreme values have a great effect on the index. Z-scores are defined as:

$$
z=\frac{x-\bar{x}}{s}
$$

The rescaling method is used to normalize index items to an identical range by linear transformation. When the rescaling method is used in this paper, all variables of the particular sub-indices are converted to a scale from 1-100 points, where 100 represents the best score and 1 represents the worst. It is defined as:

$$
y=\frac{x-\min (x)}{\max (x)-\min (x)}
$$

Rescaling is vulnerable to extreme values or outliers that can distort the transformation. However, it can widen the range of indicators lying within small intervals more than using the $z$-scores transformation. Considering our data, where the values of the variables are rather close to each other for some determinants, the rescaling method seems most appropriate because it widens the countries' spread and, thus, allows easier interpretations.

\subsubsection{Weighting of the Index Items}

In addition to the normalization and standardization of the data series, the weightings of the index items have to be determined before the aggregation can be conducted. We follow two schemes. We use equal weights for all data series and key drivers according to the structure presented in Table 1, and we use weights determined by factor analyses on the level of the 4 key drivers. According to Nardo et al. (2005a), most composite indices rely on equal weighting. This is the straightforward approach and we realize later that the equal weighting scheme does not differ to a great extent from the one resulting from factor analyses.

When using factor analysis, each component is assigned a weight according to its contribution to the total variance in the data. This ensures that the resulting summary indicators account for a large part of the cross-country variance of the underlying items. Nicoletti et al. (2000) highlight that the properties of factor analyses are particularly desirable for cross-country comparisons. A more detailed discussion of factor analyses can be found in Hair et al. (1998). Furthermore, Nardo et al. (2005b) discuss the advantages and disadvantages of factor analyses. They describe that the basic idea behind factor analysis is that it might be possible to describe a set of $Q$ variables in terms of a smaller number of $\mathrm{m}$ factors. In a general form the factor analysis model is given by: 


$$
\begin{aligned}
& \mathrm{x}_{1}=\alpha_{11} \mathrm{~F}_{1}+\alpha_{12} \mathrm{~F}_{2}+\ldots+\alpha_{1 \mathrm{~m}} \mathrm{~F}_{\mathrm{m}}+\mathrm{e}_{1} \\
& \mathrm{x}_{2}=\alpha_{21} \mathrm{~F}_{1}+\alpha_{22} \mathrm{~F}_{2}+\ldots+\alpha_{2 \mathrm{~m}} \mathrm{~F}_{\mathrm{m}}+\mathrm{e}_{2} \\
& \ldots \\
& \mathrm{x}_{\mathrm{Q}}=\alpha_{\mathrm{Q} 1} \mathrm{~F}_{1}+\alpha_{\mathrm{Q} 2} \mathrm{~F}_{2}+\ldots+\alpha_{\mathrm{Qm}} \mathrm{F}_{\mathrm{m}}+\mathrm{e}_{\mathrm{Q}}
\end{aligned}
$$

Thereby $x_{i}$ is a variable with zero mean and unit variance; $a_{i 1}, a_{i 2}, \ldots, a_{i m}$ are the factor loadings related to variable $\mathrm{X}_{\mathrm{i}} ; \mathrm{F}_{1}, \mathrm{~F}_{2}, \ldots, \mathrm{F}_{\mathrm{m}}$ are $\mathrm{m}$ uncorrelated common factors with zero mean and unit variance; while $e_{i}$ are the $Q$ specific factors supposed independently and identically distributed with zero mean. Nardo et al. (2005b) emphasize that, to deal with that model, the most commonly used method in the development of composite indicators is principal component analysis (PCA). It extracts the first $m$ principal components and considers them as factors and neglects the remaining.

Cronbach's Alpha over our four key drivers is 0.874 and, thus, underlines the quality of data selection for all the countries. The MSA value is 0.837, and Bartlett's Test is significant at 0.000. Table 5 illustrates the results after applying the PCA. One single component is extracted that represents $82 \%$ of the total variance of the underlying data.

\section{Table 5}

Result of factor analysis

\begin{tabular}{|c|c|c|c|c|c|c|}
\hline \multirow{2}{*}{ Component } & \multicolumn{3}{|c|}{ Initial Eigenvalues } & \multicolumn{2}{c|}{ Extraction Sums of Squared Loadings } \\
\cline { 2 - 7 } & Total & \% of Variance & Cumulative \% & Total & \% of Variance & Cumulative \% \\
\hline 1 & 3.281 & 82.014 & 82.014 & 3.281 & 82.014 & 82.014 \\
2 & 0.371 & 9.279 & 91.293 & & & \\
3 & 0.207 & 5.174 & 96.467 & & & \\
4 & 0.141 & 3.533 & 100.000 & & & \\
\hline
\end{tabular}

Table 5 depicts the results of the factor analysis which merits discussion. The high Cronbach Alpha and MSA value, and extracting the one factor that explains such a large part of the data variance, mean that the key drivers are adequate joint proxies for a single latent factor. They are unidimensional, and express one characteristic. The economic interpretation of this result is that our choice of key drivers is appropriate for our purpose to assess FDI attractiveness for countries. This attractiveness is excellently measured by using the four criteria (Economic Activity, Legal and Political System, Business Environment, and a country's Infrastructure) as proxies.

The last step deals with the calculation of the weights for the four key drivers. The square of a factor loading represents the proportion of the variance of the indicator explained by the factors. The component weight of a sub-index is received by dividing the square of a component loading with the variance explained by the model. Table 6 presents the component loadings and the resulting weights for the individual key drivers. 


\section{Table 6}

Resulting weights for the four key drivers

\begin{tabular}{|lcc|}
\hline & Component & Weight \\
\hline 1. Economic Activity & 0.919 & 0.257 \\
2. Legal and Political System & 0.938 & 0.268 \\
3. Business Environment & 0.849 & 0.220 \\
4. Infrastructure & 0.914 & 0.255 \\
\hline
\end{tabular}

Table 6 illustrates that Legal and Political System and Infrastructure receive the highest weight, while Business Environment receives the lowest. This means, "if we let the data speak," that the legal and political environment in a particular country is the strongest determinant of FDI activity. However, there is only a small difference with respect to an equal weighting scheme. Therefore, the factor analysis does not change the results of the index to a major extent.

\subsubsection{Aggregation}

According to Nardo et al. (2005a and 2005b), aggregation methods can be distinguished in additive methods, geometric aggregation, and non-compensatory multi-criteria analysis. We use the linear and geometric aggregation method because they are the most adequate for our purpose. Nardo et al. (2005a) argue that linear aggregation assigns base indicators proportionally to the weights. Ebert and Welsch (2004) stress that linear aggregation is useful when all sub-indicators have the same measurement unit.

Linear aggregation is defined as:

$$
\bar{x}=\sum_{i} w_{i} x_{i}, \quad \text { where } 0 \leq w_{i} \leq 1, \text { and } \sum_{i} w=1
$$

According to Nardo et al. (2005a), geometric aggregation rewards those countries or those subindicators with higher scores. Ebert and Welsch (2004) argue that geometric aggregation is better suited if non-comparable and strictly positive sub-indicators are expressed in different ratio scales.

Geometric aggregation is defined as:

$$
\bar{x}=\prod_{i} x_{i}^{w_{i}}, \text { where } 0 \leq w_{i} \leq 1 \text {, and } \sum_{i} w=1
$$

Analogue to the two different weighting schemes we propose, we have no preference with respect to the aggregation method and will both methods when calculating the index.

\subsection{Explanatory Power of the Results}

After the introduction of all techniques used to check the consistency of the index, to standardize and normalize the data series, to calculate the weightings, and finally to aggregate the sub-indices in order to receive the overall index results, this section compares the explanatory power of all the combinations we presented in Table 3 to calculate different index versions. We refer to the best method then as "Our FDI Index." We test the explanatory power 
of our different index versions by comparing them with the actual FDI activity in the particular countries. The FDI inward flows are published in the Balance of Payments. Intuitively, the FDI inward flows should represent an adequate indicator of a country's attractiveness to foreign investors. Hence, there should be a strong correlation between the index scores and the actual FDI inward flows in the particular countries. To ensure comparability of the various countries, we deflate FDI by economic size. Furthermore, to take into account the high fluctuation of the FDI inward flows, we use an average over three years to smooth the fluctuations. Further, we drop outliers with very high, very low, and strongly fluctuating (e.g., from negative to positive) FDI from the sample. The criteria to drop a country from the sample is when the ratio of the standard deviation of FDI and the three-year average of FDI/GDP is larger than 0.5. We calculate the Pearson Correlation of the three-year average of FDI/GDP and the scores of the proposed four different index versions and present the results in Table 7.

\section{Table 7}

Tracking power of the different index versions

\begin{tabular}{|lc|}
\hline Index Calculation Method & $\begin{array}{c}\text { Correlation with FDI Inward Flows } \\
\text { (Two-tailed significance level) }\end{array}$ \\
\hline Method 1: Z-scores, equal, linear & $\mathbf{0 . 5 4 3 ( 0 . 0 0 0 )}$ \\
Method 2: Rescaling, equal, linear & $0.521(0.000)$ \\
Method 3: Rescaling, equal, geometric & $0.523(0.000)$ \\
Method 4: Rescaling, factor, linear & $0.519(0.000)$ \\
\hline
\end{tabular}

Table 7 reveals the following:

a) According to the correlation analyses, the most adequate method for measuring the attractiveness of a country for FDI investors is method 1 ( $\rho=0.543)$.

b) The additional effort to perform a factor analysis leads to slightly worse results.

c) Geometric aggregation performs better than linear aggregation.

Considering these findings, we subsequently present the result of calculation method 1, using z-scores to standardize the data series, equal weightings, and the linear aggregation technique.

\section{Results}

We calculate Our FDI Index according to the approach discussed previously, and present a ranking for 127 countries in Figures 2 and 3. Figure 2 includes the first half of the countries and Figure 3 the second. We determine the GDP-weighted average index score for the world (as represented by all of our sample countries), and chose this as a benchmark rescaled to 100 to simplify country and regional comparisons. Lack of space prevents us from commenting on all the individual countries. ${ }^{7}$ Therefore, we briefly focus on the leading and trailing countries before we discuss general differences between emerging and developed regions.

\footnotetext{
${ }^{7}$ We can provide detailed analyses as presented in Figures 4 and 5 on request. 
a) Best performing countries - Singapore, Hong Kong, Luxembourg, and the United Arab Emirates are the leading countries in the ranking. All four countries perform above average regarding all index items. Singapore is the best performing economy in two of four key drivers, namely Business Environment and Legal and Political System. Besides that, it is ranked second for strong Economic activity and fifth for Infrastructure. Business Monitor International (2006) confirms that Singapore is highly attractive for foreign investors due to the stable, non-corrupted political environment, low levels of bureaucracy, a very good developed infrastructure, and a highly attractive market orientation, which makes it easy and profitable to conduct business in Singapore. Hong Kong is ranked second and receives the most index points for its high-quality infrastructure worldwide. The latter is also described by Economist Intelligence Unit (2008a), which argues that Hong Kong's telecommunications infrastructure, in particular, is excellent. Furthermore, according to Economist Intelligence Unit (2008a), Hong Kong's international airport, rail infrastructure, and container port rank among the best and busiest in the world. Hong Kong is also ranked third for both Economic Activity and Legal and Political System, and is ranked fourth for Business Environment. Economist Intelligence Unit (2008a) describes Hong Kong's advantage as its role as an operations centre for companies doing business in China. This role is mainly achieved due to the superior infrastructure and regulatory systems. In addition, Hong Kong attracts foreign investors due to no restrictions on foreign ownership of shares. Closely behind the two leading economies and Luxembourg, comes the United Arab Emirates ranked fourth. The United Arab Emirates mainly receives high ratings due to enormous central government gross surplus, a very attractive market size and potential and outstanding profit and capital gains taxes. Economist Intelligence Unit (2008b) confirms that the United Arab Emirates achieves very high surpluses mainly due to its oil and gas production. With these surpluses the United Arab Emirates has generated vast sovereign wealth funds, valued at over $\$ 600$ billion. In addition, Economist Intelligence Unit (2008b) reports that free zones, which offer highly attractive taxation, play a central role in the development of non-oil economy in the United Arab Emirates.

b) Worst performing countries - Venezuela, East Timor, Burundi, Zimbabwe, and Chad are the worst performing countries in our index. Those countries show strong deficits in almost all criteria that affect the investment decisions of foreign investors. Scoring fewer than 3 index points for the existing legal and political system, they are much less attractive than the world average benchmark. The Economist Intelligence Unit (2009) reports, for example, that due to political conflicts in 2002-2004, Venezuelan FDI inflows declined sharply. The Business Environment only looks slightly better, where Venezuela gains 10 index points. This is also confirmed by Economist Intelligence Unit (2009), which argues that the uncertain business climate in Venezuela leads to disinvestment by foreign investors. Even though Venezuela has very strong real GDP growth, overall economic activity receives only 34 index points due to very poor performance regarding the openness of its economy. The lack of economic openness in Venezuela is described, for instance, by UNCTAD (2008b) regarding the oil and gas industry. UNCTAD (2008b) stresses that countries like Venezuela adopted policy changes in 2007 to further restrict or even prohibit foreign investment in oil and gas. In addition, as discussed in UNCTAD (2006 and 2007), other reasons for Venezuela's low performance are drastic changes in the tax regime and contractual relations with private firms, as well as the dominant position or exclusive presence of stateowned companies in the oil and gas industry. Finally, Venezuela receives only 38 index points for Infrastructure. In particular the quality of transportation and energy supply cannot compete with international standards. 


\section{Figure 2}

Country ranking according to our FDI index - first half of the countries

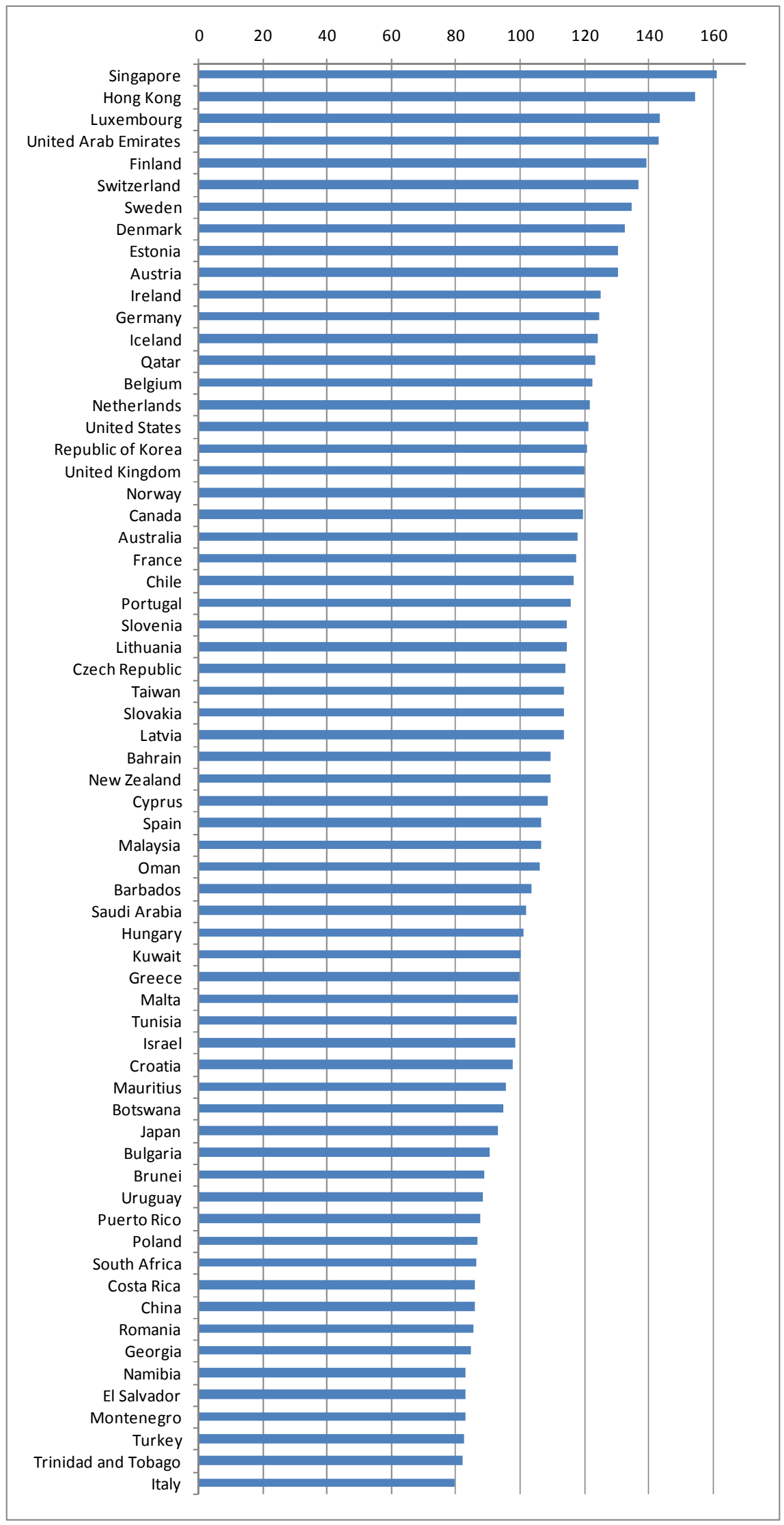




\section{Figure 3}

Country ranking according to our FDI index - second half of the countries

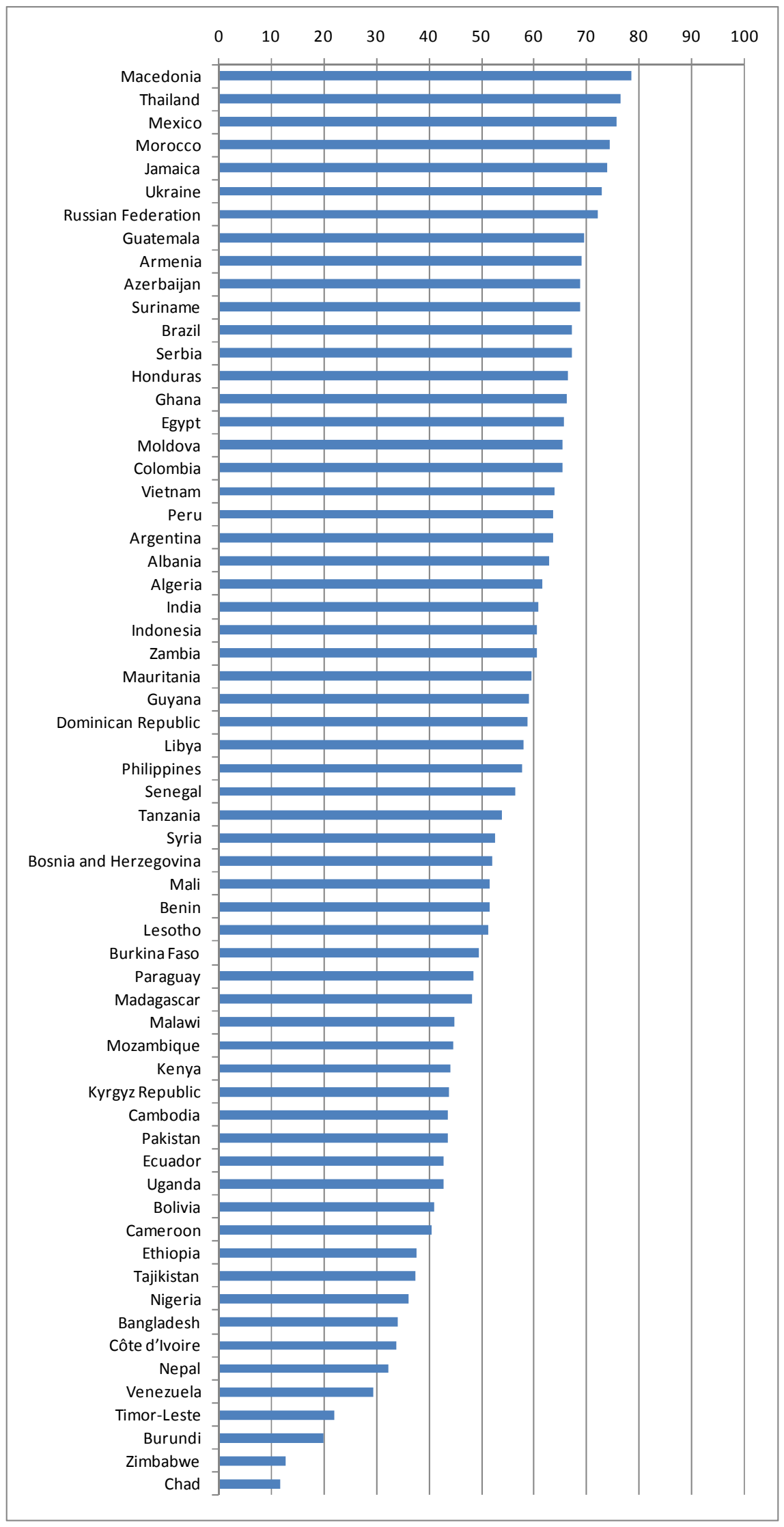




\subsection{Advanced Economies vs. Emerging and Developing Economies}

UNCTAD (2008b) finds that about three quarters of world inward FDI stocks are received by advanced economies and therefore the FDI inward flows still remain concentrated. Our FDI Index allows the tracing back of indicator values to increasing level of detail and, therefore, provides the possibility of conducting detailed strength and weakness analyses. These analyses contribute to resolving the question of why the emerging and developing economies lag behind the advanced economies in attracting FDI inflows. The provided information can be used by policy-makers to improve their country's attractiveness for foreign investors. We follow the IMF (2008) definition of a) advanced economies and b) emerging and developing economies, and present the four key driving forces and the level 2 determinants for both groups in Figures 4 and 5.

\section{Figure 4}

Advanced economies vs. emerging and developing economies - strengths and weaknesses (in the four key drivers)

\section{Economic Activity}

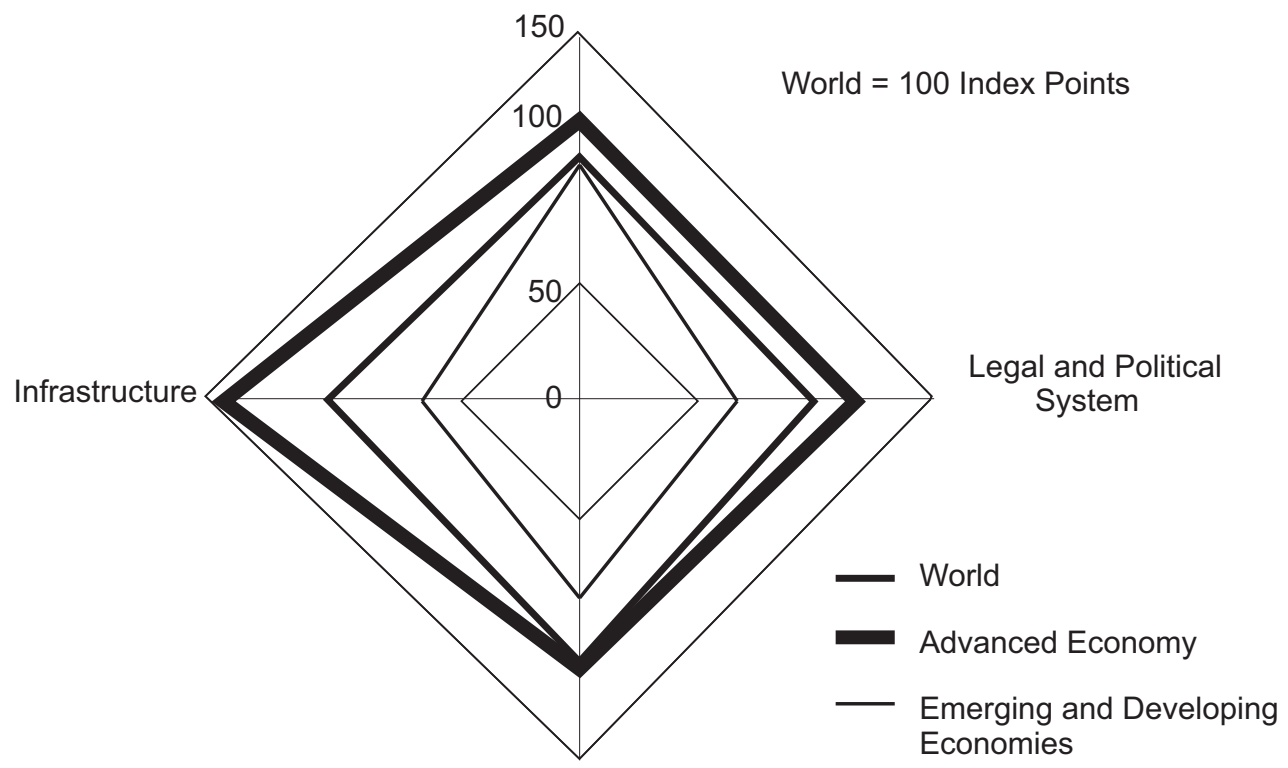

Business Environment 


\section{Figure 5}

Advanced economies vs. emerging and developing economies - strengths and weaknesses (the sub-indices)

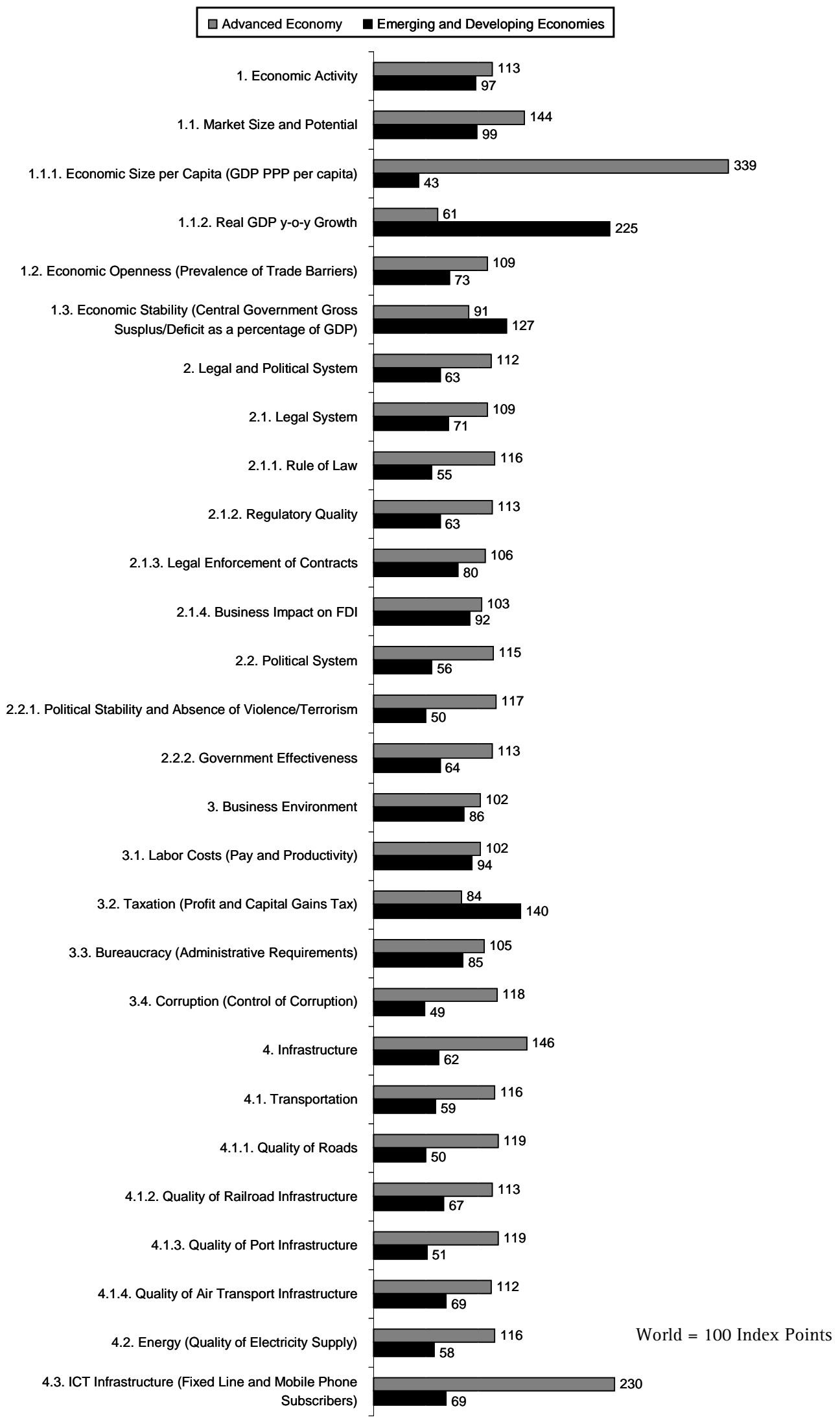


Figure 4 illustrates the strengths and weaknesses in the four key drivers of advanced economies in comparison with emerging and development economies. Figure 5 shows the comparison for all sub-indices. The graphs confirm what we know from the literature and from daily experience on the differences between emerging and developed markets. We subsequently comment on the results for each key driver of Our FDI Index.

a) Economic Activity - The gap between advanced economies and emerging and developing economies regarding this key driver is not that great. With 97 index points, the emerging and developing economies only perform 3\% worse than the world average benchmark. However, a deeper look at the level 2 and 3 sub-indices reveals large differences. The strengths of the advanced economies can be clearly identified. They outperform the emerging and developing economies due to their market size and their economic openness. The emerging and developing economies, on the other hand, receive high ratings for economic growth and economic stability. However, the latter is mainly caused by the enormous central government gross surpluses from the Middle Eastern countries.

b) Legal and Political System - Regarding the legal and political system, we identify a large gap between the two groups. The emerging and developing economies receive only 63 index points for this key driver. Especially due to the existing political instability and the rule of law, the emerging and developing economies are far less attractive for foreign investors than the advanced economies. Al Nasser (2007) confirms that Latin American and Asian countries can encourage FDI inflows by reducing political instability and by developing a more efficient legal framework.

c) Business Environment - With respect to taxation, the gap between the two country groups is not very large. However, corruption remains a big obstacle for emerging and developing countries to receive FDI. Al Nasser (2007) confirms that emerging countries can improve their attraction for foreign investors by reducing corruption.

d) Infrastructure - Emerging and developing economies lag far behind the advanced economies regarding infrastructure quality. This is confirmed by UNCTAD (2008b). ${ }^{8}$ In particular UNCTAD (2008b) argues that developing countries' needs for investments in infrastructure exceed the amounts currently planned. In addition, they stress that such investment needs are even growing with increasing population, rapid economic growth, and urbanization. World Bank (2009) estimates that, in order to sustain broader economic growth and poverty reduction, developing countries should invest 7-9\% of their GDP annually for both new investment and the maintenance of existing infrastructure. However, they are investing only $3-4 \%$ on average.

\subsubsection{Critical Aspects of Our FDI Index - Benchmarking Against other Indices}

Our approach to constructing a composite measure for the attractiveness of countries to receive FDI is not above criticism. For example, Nardo et al. (2005a) stress that subjective decisions have to be made in the construction process of composite indicators. This includes the selection of sub-indicators, the treatment of missing values, the choice of the aggregation model, the weights of the indicators, etc. These choices, together with the information provided by the data, shape the message communicated by the composite indicator. Additionally, if composite

\footnotetext{
${ }^{8}$ UNCTAD (2008b) uses a slightly different country classification. The most recent country classification is used in this paper, as described above. Nevertheless, the differences between these two classifications are not significant.
} 
indicators are poorly constructed or misinterpreted, they can send misleading or weak policy messages. Furthermore, the selection of data series and the index structure remain arguable. Additional data series might be included, or some of them might be exchanged by different ones. Also, the quality of some data might be poor due to heterogeneous data gathering methods in the different economies. Finally, the number of data series is arguable as well. Fewer or more items might be more appropriate to predict a host country's FDI attractiveness.

To account for this criticism, we perform a benchmark analysis to provide evidence for the adequacy of our approach. We compare the tracking power of Our FDI Index with those of other indices developed for the assessment of general investment and business conditions or FDI activity in various countries.

We detect three alternative indices that cover a similar topic and a similar country sample that we consider in the analyses. The first is constructed to directly evaluate FDI investment behavior. The second measures the general competitiveness of economies. We use it to analyze whether it is necessary to focus on determinants for FDI, or if the investment behavior of foreign investors is better described by focusing on the general competitiveness of an economy. Finally, Our FDI Index is benchmarked against an even more focused index to determine whether a more severe view of the parameters of FDI inward flows can increase the explanatory power of the results. Therefore, we analyze whether an index focusing on trade similarly qualifies as describing the investment behavior of FDI investors.

We therefore benchmark Our FDI Index with the following indices:

a) Focus on FDI - FDI Inward Potential Index 2004-2006 ${ }^{9}$

b) Focus on the competitiveness of an economy - The Global Competitiveness Index 2008$2009^{10}$

c) Focus on a key determinant - The Enabling Trade Index $2008^{11}$

However, the benchmark indices and Our FDI Index do not include the same country sample. Therefore, we reduce the list of covered countries for all indices to a common level, to obtain a fair benchmarking result. Since the other indices include more countries, we discard several from their samples. The tracking power of the different indices is presented in Table 8.

\section{Table 8}

Tracking power of other indices

\begin{tabular}{|lc|}
\hline Index & $\begin{array}{c}\text { Correlation with FDI } \\
\text { Inward Flows }\end{array}$ \\
\hline Our FDI Index & $\mathbf{0 . 5 4 3}$ \\
Inward FDI Potential Index 2004-2006 & 0.310 \\
The Global Competitiveness Index 2008-2009 & 0.315 \\
The Global Enabling Trade Index 2008 & 0.440 \\
\hline
\end{tabular}

\footnotetext{
${ }^{9}$ See http://www.unctad.org/Templates/WebFlyer.asp?intItemID=2472\&lang=1.

${ }^{10}$ Schwab and Porter (2008).

${ }^{11}$ Lawrence et al. (2008).

${ }^{12}$ For the correlation analysis of the Inward FDI Potential Index 2004-2006, the three-year average of the FDI inward flows from 2002-2004 is used.
} 
The benchmarking analysis reveals that Our FDI Index is the most adequate indicator for real FDI activity. The rationale for this outperformance is related to the (quality of the) individual data series we use, and the weighting that results from our index structure. Broader indices that measure country competitiveness should not be used to assess the investment behavior of foreign investors. This finding underlines the fact that it is inevitable to focus on those factors, identified here, that affect the investment decisions of foreign investors to determine a host country's attraction for inward FDI. Further, as revealed by the inferior tracking power of the Global Enabling Trade Index, the exclusive view on particular determinants also leads to a less adequate measure for FDI inflows. Hence, it is worth the effort of gathering all the individual data series, and applying our aggregation method and weighting structure to calculate our FDI Index.

\section{Conclusion and Outlook}

We present a composite index to measure a host country's attractiveness for Foreign Direct Investment. Therefore, we review the literature on FDI determinants and identify the factors that affect a host country's attraction for FDI. These factors can be divided into four categories which are referred to as key drivers: Economic Activity, the Legal and Political System, the Business Environment, and Infrastructure. We seek data series and ready-made indices to assess these determinants for as many countries as possible. The task is to find adequate measures that share common characteristics with the identified factors. As a result we propose an index structure, based on 20 different data series, which enables us to cover 127 countries.

For the index construction, we propose a pyramidal structure with three index levels. The main advantage of this structure is that it allows the tracing back of index values to an increasing level of detail. This is valuable for a detailed presentation of strengths and weaknesses of countries or regions. Our analyses are helpful for policy-makers not only to benchmark their country against others, but also to draw conclusions on how to improve their country's attraction for receiving FDI. Different methods for calculating Our FDI Index, namely for normalization, weighting, and aggregation, are introduced. Since the index results are sensitive to these techniques, we propose four alternative index versions. We measure the explanatory power of these alternatives by correlating the country scores with actual FDI inward flows. We identify the index version with the highest tracking power of 0.543 across our countries.

The results reveal that Singapore is the most attractive country for FD investors. Singapore receives the most index points for its legal and political system and for its business environment. In addition, it is ranked second for its economic activity and fifth for its infrastructure. Hong Kong is ranked second and receives the most index points for its highquality infrastructure worldwide. The countries at the bottom of our ranking are Venezuela, East Timor, Burundi, Zimbabwe and Chad. They lag behind with respect to almost all criteria that affect the investment decisions of foreign investors. Lack of space prevents us from commenting on particular countries, but we can provide detailed analyses as presented in Figures 4 and 5 on request.

Our FDI Index provides further explanation as to why FDI inward flows still remain concentrated and why advanced economies still count for three quarters of world inward FDI. A strength and weakness analysis reveals the existing differences between advanced economies and emerging/developing economies. Mainly due to poor performance regarding two key 
drivers, Legal and Political System and Infrastructure, the latter are less attractive for foreign investors. Further, the advanced economies receive high ratings for their market size and openness. Compared to this, emerging and developing economies receive good scores for Economic Growth. Based on the identified differences, and especially on the basis of the identified obstacles for FDI in emerging and developing economies, policy-makers can evaluate how to improve their country performance with respect to attracting FD investors.

To gain further information about the quality of the results, we benchmark Our FDI Index with three others focusing directly on FDI attraction, on general country competitiveness, and exclusively on particular FDI determinants. The analyses reveal that Our FDI Index yields the most adequate measure for a host country's attraction to receive FDI.

The availability of the necessary data series limits the country sample of Our FDI Index. The full data set with the required quality is not available for many emerging countries, in particular those from the African continent. The task of future research is to seek new data series that cover more countries and calculate the index according to the proposed method. This could yield even better results and would increase the comparability of regions, country groups, and continents. Further, the cross-sectional approach should be confirmed by panel analyses. We hope that the index structure and its good tracking power will be maintained over time and over a larger sample. Another aspect of further research is to attempt to increase the index tracking power with optimized weighting schemes. 


\section{References}

Addison, T. and Heshmati, A. (2003), "The New Global Determinants of FDI Flows to Developing Countries: The Importance of ICT and Democratization," in: UNU-WIDER Research Paper DP2003/45.

Akhter, S. H. (1993), "Foreign direct investments in developing countries: The openness hypothesis and policy implications," in: The International Trade Journal, Vol. 7, Issue 6, pp. 655-672.

Al Nasser, 0. M. (2007), "The Determinants of the U.S. Foreign Direct Investment: Does the Region Matter?," in: Global Economic Review, Vol. 36, Issue 1, pp. 37-51.

Asiedu, E. (2002), "On the Determinants of Foreign Direct Investment to Developing Countries: Is Africa Different?," in: World Development, Vol. 30, Issue 1, pp. 107-119.

Baniak, A., Cukrowski, J., and Herczynski, J. (2005), "On the Determinants of Foreign Direct Investment in Transition Economies," in: Problems of Economic Transition, Vol. 48, Issue 2, pp. 6-28.

Barrell, R. and Pain, N. (1996), “An Econometric Analysis of U.S. Foreign Direct Investment," in: The Review of Economics and Statistics, Vol. 78, No. 2, pp. 200-207.

Bénassy-Quéré, A., Coupet, M., and Mayer, T. (2007), "Institutional Determinants of Foreign Direct Investment,” in: World Economy, Vol. 30, Issue 5, pp. 764-782.

Bevan, A. A. and Estrin, S. (2004), "The determinants of foreign direct investment into European transition economies," in: Journal of Comparative Economics, Vol. 32, Issue 4, pp. 775-787.

Billington, N. (1999), "The location of foreign direct investment: an empirical analysis," in: Applied Economics, Vol. 31, Issue 1, pp. 65-76.

Bloningen, B. A. (2005), “A review of the empirical literature on FDI determinants," in: Atlantic Economic Journal, Vol. 33, pp. 383-403.

Business Monitor International (2006), “Attractive FDI Environment," in: Asia Monitor: South East Asia Monitor, Vol. 2, p. 5.

Cassou, S. P. (1997), “The link between tax rates and foreign direct investment," in: Applied Economics, Vol. 29, Issue 10, pp. 1295-1301.

Caves, R. E. (1971), "International Corporations: The Industrial Economics of Foreign Investment," in: Economica, New Series, Vol. 38, No. 149, pp. 1-27.

Chakrabarti, A. (2001), "The determinants of foreign direct investment: Sensitivity analyses of cross country regressions," in: Kyklos, Vol. 54, pp. 89-114.

Clausing, K. A. and Dorobantu, C. L. (2005), "Re-entering Europe: Does European Union candidacy boost foreign direct investment?, in: Economics of Transition, Vol. 13 (1), pp. 77-103.

Cortina, J. M. (1993), "What is coefficient alpha? An examination of theory and applications," in: Journal of Applied Psychology, Vol. 78, No. 1, pp. 98-104. 
Cronbach, L. J. (1951), "Coefficient alpha and the international structure of tests," in: Psychometrika, Vol. 16, Issue 3, pp. 297-334.

Cureton, E. E. and D'Agostino, R. B. (1993), "Factor Analysis: An Applied Approach," Routledge.

Ebert, U. and Welsch, H. (2004), "Meaningful environmental indices: a social choice approach," in: Journal of Environmental Economics and Management, Vol. 47, Issue 2, pp. 270-283.

Economist Intelligence Unit (2008a), “Country Profile 2008: Hong Kong,” pp. 1-25.

Economist Intelligence Unit (2008b), “Country Profile 2008: United Arab Emirates,” pp. 1-34.

Economist Intelligence Unit (2009), “Country Profile 2009: Venezuela,” pp. 24-27.

Feldt, L. S., Woodruff, D. J., and Salih, F. A. (1987), "Statistical Inference for Coefficient Alpha," in: Applied Psychological Measurement, Vol. 11, No. 1, pp. 93-103.

Franco, C., Rentocchini, F., and Marzetti, G. V. (2008), "Why do firms invest abroad? An analysis of the motives underlying foreign direct investments," SSRN Working Paper 1283573.

Freudenberg, M. (2003), “Composite Indicators of Country Performance: A Critical Assessment," OECD Science, Technology and Industry Working Papers, 2003/16, OECD Publishing.

Fung, K. C., lizaka, H. and Parker, S. (2002), "Determinants of U.S. and Japanese Direct Investment in China," in: Journal of Comparative Economics, Vol. 30, Issue 3, pp. 567-578.

Green, S. B., Lissitz. R. W., and Mulaik, S. A. (1977), "Limitations of Coefficient Alpha as an Index of Test Unidimensionality," in: Educational and Psychological Measurement, Vol. 37, No. 4, pp. 827-838.

Hair, J. F., Anderson, R. E., Tatham, R. L., and Black, W. C. (1998), "Multivariate Data Analysis," Fifth ed., Englewood Cliffs.

Hartman, D. G. (1984), “Tax Policy and Foreign Direct Investment in the United States," in: National Tax Journal, Vol. 37, No. 4, pp. 475-487.

Hattie, J. (1985), “Methodology Review: Assessing Unidimensionality of Tests and Items," in: Applied Psychological Measurement, Vol. 9, No. 2, pp. 139-164.

IMF (2008), "World Economic Outlook October 2008: Financial Stress, Downturns, and Recoveries," International Monetary Fund.

Jacobs, R., Smith, P., and Goddard, M. (2004), "Measuring performance: An examination of composite performance indicators," Centre of Health Economics, Technical Paper Series 29.

Janicki, H. P. and Wunnava, P. V. (2004), "Determinants of foreign direct investment: empirical evidence from EU accession candidates,” in: Applied Economics, Vol. 36, Issue 5, pp. 505-509.

Kaiser, H. F. and Rice, J. (1974), "Little Jiffy, Mark IV," in: Educational and Psychological Measurement, Vol. 34, No. 1, pp. 111-117.

Kobrin, S. J. (1976), "The Environmental Determinants of Foreign Direct Manufacturing Investment: An Ex Post Empirical Analysis," in: Journal of International Business Studies, Vol. 7, Issue 2, pp. 29-42. 
Kravis, I. B. and Lipsey, R. E. (1982), "The Location of Overseas Production and Production for Export by U.S. Multinational Firms," in: Journal of International Economics, Vol. 12, No. 3/4, pp. 201-223.

Lawrence, R. Z., Blanke, J., Hanouz, M. D. and Moavenzadeh, J. (2008), “The Global Enabling Trade Report 2008," World Economic Forum, Geneva.

Lim, E. G. (2001), "Determinants of, and the relation between, foreign direct investment and growth: A summary of the recent literature," IMF Working paper 01/175.

Loree, D. W. and Guisinger, S. E. (1995), "Policy and Non-Policy Determinants of U.S. Equity Foreign Direct Investment," in: Journal of International Business Studies, Vol. 26, Issue 2, pp. 281-299.

Markusen, J. R. (2000), “Foreign direct investment and trade,” CIES Policy Discussion Paper 0019.

Miller, M. B. (1995), "Coefficient Alpha: A basic introduction from the perspectives of classical test theory and structural equation modeling," in: Structural Equation Modelling, Vol. 2, No. 3, pp. 255-273.

Milner, C. and Pentecost, E. (1996), "Locational advantage and US foreign direct investment in UK manufacturing," in: Applied Economics, Vol. 28, Issue 5, pp. 605-615.

Miyamoto, K. (2003), "Human Capital Formation and Foreign Direct Investment in Developing Countries," in: Organisation for Economic Co-operation and Development (OECD), Working Paper No. 211.

Moosa, I. A. and Cardak, B. A. (2006), "The determinants of foreign direct investment: An extreme bounds analysis," in: Journal of Multinational Financial Management, Vol. 16, pp. 199-211.

Nardo, M., Saisana, M., Saltelli, A., Tarantola, S., Hoffman, A., and Giovannini, E. (2005a), "Handbook on constructing composite indicators: Methodology and user guide," OECD Statistics Working Paper STD/DOC(2005)3.

Nardo, M., Saisana, M., Saltelli, A., and Tarantola, S. (2005b), "Tools for Composite Indicators Building,” European Commission, Joint Research Centre Working Paper EUR 21682 EN.

Naudé, W. A. and Krugell, W. F. (2007), "Investigating geography and institutions as determinants of foreign direct investment in Africa using panel data," in: Applied Economics, Vol. 39, Issue 10, pp. 1223-1233.

Nicoletti, G., Scarpetta, A., and Boylaud, 0. (2000), "Summary Indicators of Product Market Regulation with an Extension to Employment Protection Legislation," OECD Economics Department Working Papers, No. 226.

Nigh, D. (1985), "The Effect of Political Events on United States Direct Foreign Investment: A Pooled Time-Series Cross-Sectional Analysis," in: Journal of International Business Studies, Vol. 16, Issue 1, pp. 1-17.

Nigh, D. (1986), "Political Events and the Foreign Direct Investment Decision: An Empirical Examination,” in: Managerial and Decision Economics, Vol. 7, No. 2, pp. 99-106. 
Nonnenberg, M. J. B. and Cardoso de Mendonça, M. J. (2004), ”The Determinants of Foreign Direct Investment in Developing Countries", Anais do XXXII Encontro Nacional de Economia [Proceedings of the 32th Brazilian Economics Meeting], No. 061.

Noorbakhsh, F., Paloni, A., and Youssef, A. (2001), "Human Capital and FDI Inflows to Developing Countries: New Empirical Evidence,” in: World Development, Vol. 29, Issue 9, pp. 1593-1610.

Nunnally, J. (1978), "Psychometric Theory,” New York.

OECD (2008), “OECD Benchmark Definition of Foreign Direct Investment," $4^{\text {th }}$ ed., Organisation for Economic Co-operation and Development.

Pantelidis, P. and Nikolopoulos, E. (2008), “FDI attractiveness in Greece," in: International Advances of Economic Research, Vol 14, pp. 90-100.

Ramcharran, H. (1999), "Foreign direct investment and country risk: Further empirical evidence," in: Global Economic Review, Vol. 28, Issue 3, pp. 49-59.

Ramcharran, H. (2000), "Foreign Direct Investments in Central and Eastern Europe: An Analysis of Regulatory and Country Risk Factors," in: American Business Review, Vol. 18, Issue 2, pp. 1-8.

Raykov, T. (1998), "Cronbach's Alpha and Reliability of Composite with Interrelated Nonhomogenous Items," in: Applied Psychological Measurement, Vol. 22, pp. 375-385.

Rodriguez, X. A. and Pallas, J. (2008), "Determinants of foreign direct investment in Spain," in: Applied Economics, Vol. 40, Issue 19, pp. 2443-2450.

Root, F. R. and Ahmed, A. A. (1979), "Empirical Determinants of Manufacturing Direct Foreign Investment in Developing Countries," in: Economic Development and Cultural Change, Vol. 27, No. 4, pp. 751-776.

Saggi, K. (2002), “Trade, Foreign Direct Investment, and International Technology Transfer: A Survey," in: The World Bank Research Observer, Vol. 17, No. 2, pp. 191-235.

Scaperlanda, A. E. and Mauer, L. J. (1969), "The Determinants of U.S. Direct Investment in the E.E.C.," in: The American Economic Review, Vol. 59, No. 4, Part 1, pp. 558-568.

Schneider, F. and Frey, B. S. (1985), "Economic and Political Determinants of Foreign Direct Investment,” in: World Development, Vol. 13, No. 2, pp. 161-175.

Schwab, K. and Porter, M. E. (2008), “The Global Competitiveness Report 2008-2009," World Economic Forum, Geneva.

Shatz, H. J. and Venables, A. J. (2000), “The Geography of International Investment,” The World Bank, Policy Research Working Paper No. 2338.

Singh, H. and Jun K. W. (1995), "Some new evidence of foreign direct investment in developing countries,” World Bank Policy Research Working Paper 1531.

Torrisi, C. R., Delaunay, C. J., Kocia, A., and Lubieniecka, M. (2008), "FDI in Central Europe: Determinants and Policy Implications," in: Journal of International Finance and Economics, Vol. 8, No. 4, pp. 136-147. 
UNCTAD (2006), "World Investment Report 2006: FDI from Developing and Transition Economies: Implications for Development," United Nations Conference on Trade and Development.

UNCTAD (2007), ”World Investment Report 2007: Transnational Corporations, Extractive Industries and Development," United Nations Conference on Trade and Development.

UNCTAD (2008a), “Development and Globalization: Facts and Figures 2008," United Nations Conference on Trade and Development.

UNCTAD (2008b), "World Investment Report 2008: Transnational Corporations and the Infrastructure Challenge," United Nations Conference on Trade and Development.

Vogiatzoglou, K. (2007), "Vertical Specialization and New Determinants of FDI: Evidence from South and East Asia," in: Global Economic Review, Vol. 36, No. 3, pp. 245-266.

Wei, S.-J. (2000a), "How Taxing is Corruption on International Investors?," in: The Review of Economics and Statistics, Vol. 82, No. 1, pp. 1-11.

Wei, S.-J. (2000b), "Local Corruption and Global Capital Flows," in: Brookings Papers on Economic Activity, Vol. 31, Issue 2000-2, pp. 303-354.

Wheeler, D. and Mody, A. (1992), "International investment location decisions: The case of U.S. firms," in: Journal of International Economics, Vol. 33, Issue 1-2, pp. 57-67.

World Bank (2009), “Infrastructure,” Issue Briefs, available at http://go.worldbank.org/RSG3R6K6Q0. 